\title{
Feasibility study of manufacturing concrete eco-blocks using marble sludge powder as raw materials
}

\author{
F. J. Aukour \\ Faculty of Natural Resources and Environment, \\ The Hashemite University, Jordan
}

\begin{abstract}
Marble waste, in the form of sludge obtained from the marble cutting industry, was incorporated in the mixture formulations of concrete block. The possibility of using marble sludge powders (MSPs) as a substitute for limestone was investigated over a three year period. The production of cement block from sludge was standardised in terms of process and content. Interpretation of the results have shown that appropriate incorporation of MSP can result in favourable characteristics in terms of compression strength $9 \mathrm{~N} / \mathrm{nm}^{2}$ at 28 days, and water absorption (7\%), anticipating a complimentary usage of sludge as a by-product instead of being waste.
\end{abstract}

Keywords: eco-construction blocks, marble sludge powder, cement, sustainability, environment, waste re-use.

\section{Introduction}

Nowadays, the growing consumption of available natural resources as raw materials in industry leads to their decreasing quantity, as well as quality, in nature. In addition, the marble cutting industry generates a high volume of wastes.

The most important issue that forms the basis of this project is that the amount of construction and demolition waste in landfill sites and municipalities side roads is expected to increase in the near future at international levels.

Several research projects are being conducted by incorporation of these waste materials to reduce their environmental impact, especially after being air dried. 
The waste of the Marble Cutting Industry (MCI) comes in the form of small and irregular pieces, which are sold to chip manufacturers, and sludge. The waste composes about $20-25 \%$ of the total volume [3,6]. The produced sludge was treated in settlement tanks to separate water with about $70 \%$ of the total sludge volume from mud or wet powders.

As an industrial concept and for the sustainable development of natural resources, waste might be used as a by-product in some other industry. The use of industrial waste materials as alternatives, and sometimes as additives, in the construction and manufacturing of the ceramic industry [5] and their products aims to limit the use of natural raw materials in construction [2].

The use of marble dust collected during the shaping process of marble in the asphalt mixtures as a filler material can be considered as an alternative [7]. Puzinauskas [11] and Terzi [13] have investigated the use of marble sludge mixtures as filler materials in asphalt manufacturing.

Other investigators have used Marble Sludge (MS) in metal contaminated soil to reduce the available heavy metal concentration (remediation) [10]. Therefore, the detrimental effects of the cement and concrete industry to the environment can be reduced $[8,9]$, as well as the marble industry.

The MCI faces extra costs in disposing of MS in terms of availability off site, transport and charges to local municipalities. So, any cost effective method to dispose of MS will be welcomed and encouraged by the industry itself and environmental agencies (see [12]).

So, marble sludge powder (MSP) has been thoroughly investigated as a component of concrete brick formation. Different compositions and concentrations have been tried with limited success in terms of quality.

The aim of this study was to incorporate the MSP in the concrete block industry and to evaluate the quality of the produced brick in comparison to standards and commercial requirements. This study identified the primary opportunities, constraints, and means to divert MSPs from the solid waste stream.

\section{Methodology}

\subsection{Collecting of MSPs}

The produced sludge was collected directly from the settlement tanks in which there are not any external materials (wood parts, plastics, etc.). The as-received marble sludge was air dried and crushed in a hammer-mill to get a fine powder. The air dried powder was mixed with water for sieving purposes.

\subsection{Characterization of MSPs}

The produced MSP was sieved (in No. 200 sieve, Table 1) and graded. Then it was mixed with limestone, cement (CEM-II/A-P 42,5N) and water using an agitator blender in different concentrations (Table 2). 
Table 1: $\quad$ Grading of marble powders.

\begin{tabular}{|c|c|}
\hline Sieve size & \% MS Particles \\
\hline $2-0.6 \mathrm{~mm}$ (No. 10) & 0.81 \\
\hline $0.6-0.3 \mathrm{~mm}$ (No.30) & 4.2 \\
\hline $0.3-0.07 \mathrm{~mm}$ (No.50) & 4.1 \\
\hline$<0.07 \mathrm{~mm}$ (No.200) & 90.89 \\
\hline
\end{tabular}

Table 2: Incorporated components and their concentration in the volume base.

\begin{tabular}{|c|c|c|c|c|}
\hline Sample/ components & $\mathrm{A}$ & $\mathrm{B}$ & Cement & MSP \\
\hline 1 & 2 & 3 & 0.51 & 4 \\
\hline 2 & 1 & 1 & 0.51 & 1 \\
\hline 3 & 2 & 2 & 0.51 & 3 \\
\hline 4 & 1 & 4 & 0.2 & 2 \\
\hline 5 & 2 & 3 & 1 & 3 \\
\hline 6 & 1 & 1 & 0.51 & 2 \\
\hline 7 & 2 & 4 & 0.2 & 3 \\
\hline 8 & 1 & 1 & 0.7 & 0 \\
\hline
\end{tabular}

Table 3: $\quad$ Detailed measurements obtained from sample number seven.

\begin{tabular}{|c|c|c|c|c|c|c|c|c|}
\hline \multicolumn{7}{|c|}{ Sample Dimensions } & \multirow{2}{*}{$\begin{array}{r}\text { No. of } \\
\text { holes } \\
\left(A_{h l}\right)\end{array}$} & \multirow{2}{*}{$\begin{array}{r}\text { No. of } \\
\text { holes } \\
\left(A_{h 2}\right) \\
\end{array}$} \\
\hline 1 & 2 & 3 & 4 & 5 & 6 & 7 & & \\
\hline 40 & 10 & 20 & 2.5 & 7.5 & 2.5 & 17.5 & 2 & 7 \\
\hline \multirow{2}{*}{$\begin{array}{l}\text { Wt. } \\
(\mathrm{Kg})\end{array}$} & \multicolumn{2}{|c|}{ Block $10 \mathrm{~cm}$} & \multirow{2}{*}{$\begin{array}{l}\text { Total } \\
\text { Area } \\
\left(\mathrm{cm}^{2}\right)\end{array}$} & \multirow{2}{*}{$\begin{array}{l}\text { Voids } \\
\text { area } \\
\left(\mathrm{cm}^{2}\right)\end{array}$} & \multirow{2}{*}{$\begin{array}{l}\text { Eff. } \\
\text { Area } \\
\left(\mathrm{cm}^{2}\right)\end{array}$} & \multirow{2}{*}{$\begin{array}{l}\text { Load } \\
(K N)\end{array}$} & \multirow{2}{*}{$\begin{array}{l}\text { Strength } \\
\left(\mathrm{Kg} / \mathrm{cm}^{2}\right)\end{array}$} & \multirow{2}{*}{$\begin{array}{l}\text { Strength } \\
\left(\mathrm{N} / \mathrm{mm}^{2}\right) \\
\text { or } \mathrm{Mpa}\end{array}$} \\
\hline & $\mathrm{A}_{\mathrm{h} 1}$ & $\mathrm{~A}_{\mathrm{h} 2}$ & & & & & & \\
\hline 10.44 & 9.8 & 103 & 400 & 112.8 & 287.2 & 201.2 & 71.5 & 7.01 \\
\hline $\begin{array}{l}\text { V, } \\
(\text { Total }) \\
\left(\mathrm{cm}^{3}\right)\end{array}$ & $\begin{array}{l}\text { V, } \\
\text { (Voids) } \\
\left(\mathrm{cm}^{3}\right)\end{array}$ & $\begin{array}{l}\text { Eff. } \\
\text { Volume } \\
\left(\mathrm{cm}^{3}\right)\end{array}$ & $\begin{array}{l}\text { Density } \\
\left(\mathrm{g} / \mathrm{cm}^{3}\right)\end{array}$ & & & & & \\
\hline 8000 & 1974.77 & 6025.23 & 2.06 & & & & & \\
\hline
\end{tabular}

Ah1: number of circles (27.5 $\mathrm{mm}$ in diameter)

Ah2: number of Ovule shape opening (smallest one with $30 \mathrm{~mm}$, the largest one with $75 \mathrm{~mm}$ in diameter).

\subsection{Treatments design}

Seven formulas (Table 2), having a certain amount of mixed materials represented in the volume base and each volume unit having its own weight, were derived from the combination of the following four components: Coarse aggregates (A), Fine aggregates (B), cement, and MSP. These were incorporated in block mixing formations in different percentages chosen as results indicated in 
some representing samples with promising and good signs after manufacturing random samples selected from the combinations. The test results were compared to a standard mix (series 8) as a control formula since it is used in the ordinary block manufacturing plants.

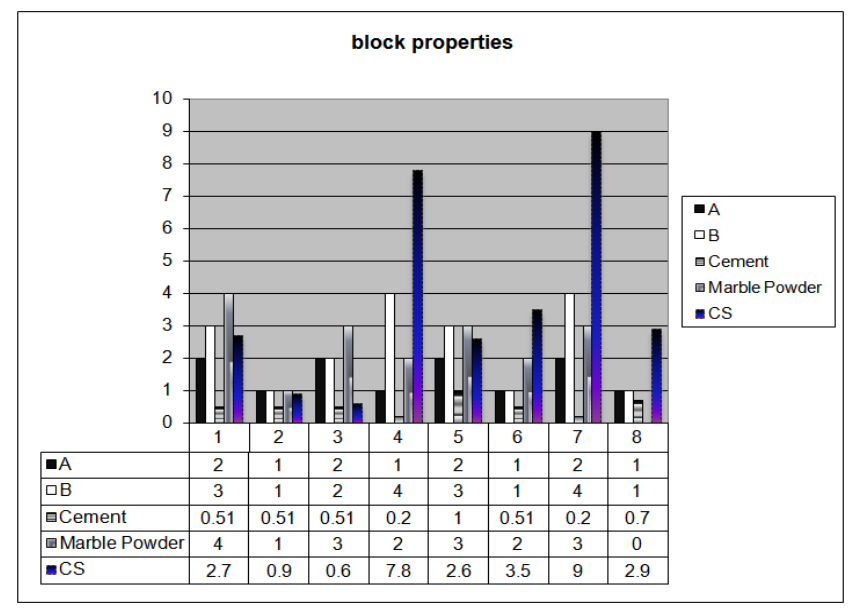

Figure 1: Compression strength behaviour in the selected series.

The produced mixtures were directly put into templates or a mould matrix (100x200x400 mm, width, height, and length respectively, Figure 2) by applying a compressive force at a rate of $600 \mathrm{k} / \mathrm{min}$ for about $50 \mathrm{~s}$ for mechanical compaction. Within the mould the produced blocks have the dimensions as illustrated in Table 3.

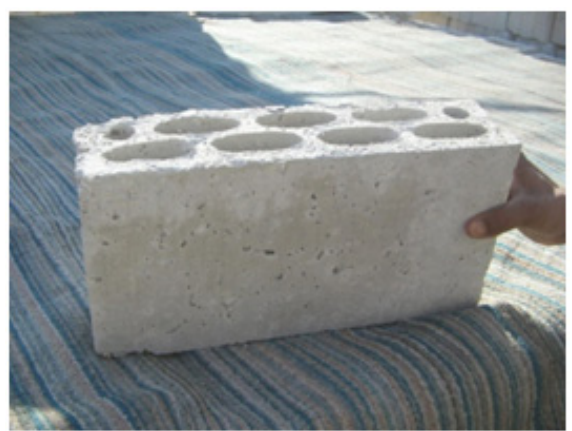

Figure 2: $\quad$ Produced $10 \mathrm{~cm}$ building block with features as in the referred to templates or mould matrix (weight $10.44 \mathrm{~kg}$ ).

After natural strengthening, and after removal from the templates, watering takes place the next day, and after air drying, these blocks were soaked in water for 24 hours, and were then removed for air drying. The next day, they were again soaked for 48 hours and then lifted for air drying for 28 days for physical 
characterization, mainly for compression strength and to pass water absorption tests (blocks or any mixed components were fired). Chemical analysis was carried out on the MSPs to determine the average chemical composition of the air dried sludge.

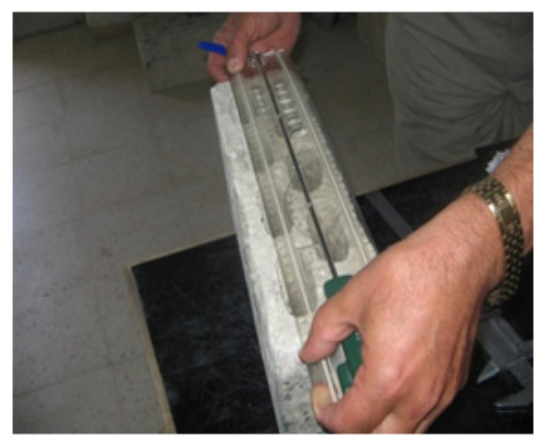

Figure 3: Dimensional measurements.

Compression strength (Cs) was determined on the produced blocks at 28 days, using a compressive testing machine with a maximum capacity of 3000 $\mathrm{kN}$. The loading was increased at a rate of $450 \mathrm{kN} / \mathrm{min}$ during pressing (Figure 4).

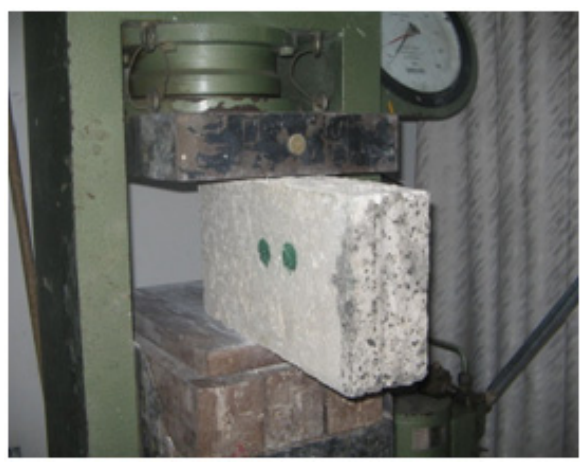

Figure 4: $\quad$ Compression strength (Cs) for incorporated blocks.

\section{Results and discussion}

The grain size distribution of MSPs shows that the main particle size was less than $0.07 \mathrm{~mm}$ in diameter $(90.9 \%)$, which might replace the very fine limestone particles that are normally incorporated in ordinary block manufacturing. Such a material can theoretically speaking reduce voids between the larger particles that form the mixture. The dimensions of the produced blocks were measured for calculation purposes as shown in Figure 3 and Table 3. The high calcium oxide 
content (49.35\%) indicates the calcite type marble of limestone origin (Table 4), in addition to small amounts of aluminium, silica, sodium, potassium and iron, and magnesium oxides are the secondary oxides detected.

The physical properties were examined (Table 5) to determine compression strength and water absorption (Table 5). The presented values of $\mathrm{Cs}$ are the average of four measurements.

Table 4: Chemical composition of MSP.

\begin{tabular}{|l|l|l|l|l|l|l|l|}
\hline Parameter & SIO2 & AL2O3 & Fe2O3 & $\mathrm{CaO}$ & $\mathrm{MgO}$ & $\mathrm{Na} 2 \mathrm{O}$ & $\mathrm{K} 2 \mathrm{O}$ \\
\hline$\%$ & 3.43 & 0.56 & 0.52 & 49.35 & 4.95 & 0.13 & 0.03 \\
\hline
\end{tabular}

From the results obtained (Figure 1), it can be seen that the compressive strength of the blocks was increased with the addition of MSP, which partially replaces the cement and fine limestone aggregates.

Table 5: $\quad$ Physical properties of the produced blocks.

\begin{tabular}{|c|c|c|}
\hline Materials Sample no. & Water Absorption & $\mathbf{C S}\left(\mathbf{N} / \mathbf{m m}^{\mathbf{2}}\right)$ \\
\hline 1 & 0.59 & 2.7 \\
\hline 2 & 1 & 0.9 \\
\hline 3 & 1 & 0.6 \\
\hline 4 & 0.17 & 7.8 \\
\hline 5 & 0.63 & 2.6 \\
\hline 6 & 0.34 & 3.5 \\
\hline 7 & 0.07 & 9 \\
\hline Blank 8 & 0.52 & 2.9 \\
\hline
\end{tabular}

The non-representing values were produced and measured (Figure 4). The blocks are of loose and fragile structure and of high-low eroded blocks as represented in series $2\left(\mathrm{Cs}\right.$ of $\left.0.9 \mathrm{~N} / \mathrm{mm}^{2}\right)$ and $3\left(\mathrm{Cs}\right.$ of $\left.0.6 \mathrm{~N} / \mathrm{mm}^{2}\right)$.

The accepted $\mathrm{Cs}$ values were compared to the Jordanian standards $(2.7$ $\mathrm{N} / \mathrm{mm} 2$ ) for four cases. In case $1, \mathrm{~A}$ and $\mathrm{B}$ are in ratio of $2: 3$. Variation taking place in the MSP leads to the fact that it can replace cement and act partially the same in cementing aggregates. Reducing the cement value by $49 \%$ volume base value (series 1) to that in series 5 of $\left(2.7 \mathrm{~N} / \mathrm{mm}^{2}\right)$, makes the possibility of increasing the MSP by one unit (volume unit) to get the same Cs value (2.7 $\mathrm{N} / \mathrm{mm}^{2}$ ).

In case 2, mixing the same quantities as the control sample $(1 \mathrm{~A}, 1 \mathrm{~B})$ of one volume unit for each cement unit, make the addition of MSP insignificant, as if we reduce the cement value by $50 \%$ with the addition of one unit of MSP (series 2 as an example) where Cs is $0.9 \mathrm{~N} / \mathrm{mm}^{2}$, while increasing MSP by one unit up to two units (series 6) and keep the other components as in series 2, the result is an increase in Cs value up to $3.5 \mathrm{~N} / \mathrm{mm}^{2}$, which is more than required. 
In case 3, the importance of MSP was clear in series 1 and 5, in that using the ratio of $2 \mathrm{~A}: 3 \mathrm{~B}$ was fixed for both. Variation in cement units by reducing the cement value to $49 \%$ in series 1 compared to series 5 makes the Cs value the same in both $\left(2.7\right.$ and $2.6 \mathrm{~N} / \mathrm{mm}^{2}$ ) when we increase MSP value one unit to replace the decrease in the cement value.

In case 4 , from the results obtained in case 3 , a further reduction in cement value was carried out. $80 \%$ out of one unit was reduced in cement value, and the variation in A, B and MSP tested. When A and B were in the ratio of 1:4 as in series 4, good results were obtained when the MSP reached a value of two units (Cs of $7.8 \mathrm{~N} / \mathrm{mm}^{2}$ ), which reflects the possibility of MSP - cement replacement (to a certain extent) accompanied by $\mathrm{A}$ and $\mathrm{B}$ values.

From case 4 , case 5 has been taken place to examine the possible increase in Cs. When A and B were in the ratio of $2: 4$ and the above cement quantity was fixed ( 0.2 unit volume), the most surprising values were obtained when the MSP was in two unit volume, where the Cs value was $9 \mathrm{~N} / \mathrm{mm}^{2}$ (series 7).

Water absorption after air drying and at 28 days were measured (Table 5) and the best results was obtained in series 4 and 7 , having the highest Cs values $(0.17$ and 0.07 respectively). Water absorption was definitely less than $7 \%$ and so the block mixtures are accepted as they obviously satisfy the ISO regulations for traditional ceramics, such as blocks, or roof and floor tiles. Thereby, there is a high tolerance for incorporating large amounts of suitable wastes as raw materials $[4,5]$, such as the case of MSP.

\section{Conclusion}

The use of MSP collected after the cutting process of marble blocks in block manufacturing mixtures was investigated. The samples, containing air dried and crushed MSP or/and limestone gravels, were prepared. Test results showed that MSP can partially replace cement in block manufacturing, which indicates the potential use of MSP as a cementing agent. Coarse aggregates are used as a filling material while fine aggregates reduce pore space between particles, which increases aggregate strength and the densification of the produced blocks. Since block manufacturing mixtures containing the MSP have significantly higher compression strength and low water absorption, the block mixtures containing MSP are recommended for construction in all its forms in that the best target market for absorbing and consuming such products is the construction sector.

MSP incorporation had a positive effect on density, shrinkage and plasticity during all stages of the production process, anticipating some modifications in the industrial production line.

\section{References}

[1] Ferreira, J. M. F., Torres, P. M. C., Silva, M. S. and Labrincha J. A., Recycling of sludges generated from natural stones cutting processes in ceramic formulations. In Proceedings of the Recycling and Waste Treatment in Mineral and Metal Processing: Technical and Economic 
Aspects, ed. B. Björkman, C. Samuelsson, and J.O. Wikström. Luleå University of Technology, Luleå-Sweden, 2002, pp. 389-396. )

[2] Francesco Colangelo et al., 2004, Properties of self - Leveling Concrete made with Industrial Wastes. International RILEM Conference on the Use of Recycled Materials in Buildings and structures, 8-11 November, 2004. Barcelona- Spain

[3] H.R. Fernandes, P. Torres, S. Agathopoulos, D. Tulyaganov and J.M.F. Ferreira, Utilization of solid wastes from granite cutting processing in porcelain industry. Al-Azhar Bulletin of Science March (2003), pp. 33-43)

[4] J.M.F. Ferreira, H.M. Alves and A.M. Mendonça, Inertization of galvanic sludges by its incorporation in ceramic products. Boletin de la Sociedad Espanola de Cerámica y Vidrio 38 (1999), pp. 127-131.

[5] J.M.F. Ferreira, P.M.C. Torres, M.S. Silva and J.A. Labrincha. Recycling of Granite sludge in brick- type and floor tile- type ceramic formulation. Waste Recycling in the ceramic industry, Euroceram News 14. (2003), pp. $1-5$.

[6] M. Dondi, B. Marsigli and B. Fabri, Recycling of industrial and urban wastes in brick production - a review, Tile Brick Int 113 [3] (1997), pp. 218-225.

[7] M. Karasahin, and S. Terzi, 2004, Use of Marble waste dust in the mixture of Asphaltic concrete as mineral filler. Euro Bitume, Viyana

[8] P. K. Mehta, Reducing the environmental impact of concrete, Concr Int 23 (2001) [10], pp 61-65.

[9] P. K. Mehta, Greening of the concrete industry for sustainable development, Concr Int 24 (2002) [7], pp. 23-27.

[10] Perez- Sirvent, C. et al., Metal - contaminated soil remediation by using sludge of the marble industry: Toxicological Evaluation. Environment International. Volume 33, Issue 4, May 2007, Pages 502-504

[11] Puzinauskas, V.P., Filler in Asphalt Mixtures, The Asphalt Institute, Research Report No. 69/2, Maryland, USA, 1983.

[12] R.R. Menezes, H.S. Ferreira, G.A. Neves and H.C. Ferreira, The use of granite wastes as ceramic raw materials. Cerâmica 48 (2002), pp. 92-101

[13] Terzi, S., An Investigation of use of marble dust in asphalt concrete as mineral filler, MSc thesis, S. Demirel University, Institute of Science. Isparta, Turkey 2000. 